\title{
Effects of Heavy Metal Pollution of Apple Orchard Surface Soils Associated with Past Use of Metal-Based Pesticides on Soil Microbial Biomass and Microbial Communities
}

\author{
Masakazu Aoyama*, Ryo Tanaka \\ Faculty of Agriculture and Life Science, Hirosaki University, Hirosaki, Japan. \\ Email: ${ }^{*}$ aoyamam@cc.hirosaki-u.ac.jp \\ Received January $26^{\text {th }}, 2013$; revised February $28^{\text {th }}, 2013$; accepted April $2^{\text {nd }}, 2013$
}

Copyright (C) 2013 Masakazu Aoyama, Ryo Tanaka. This is an open access article distributed under the Creative Commons Attribution License, which permits unrestricted use, distribution, and reproduction in any medium, provided the original work is properly cited.

\begin{abstract}
Apple orchard surface soils in Japan are polluted with copper $(\mathrm{Cu})$, lead $(\mathrm{Pb})$, and arsenic $(\mathrm{As})$ due to long-term use of metal-based pesticides. We investigated the effects of heavy metals accumulated in the surface soils in apple orchards on the microbial biomass and the microbial communities. Soil samples were taken from a chestnut orchard (unpolluted control) and five apple orchards with different degrees of heavy metal pollution. Total concentrations of $\mathrm{Cu}, \mathrm{Pb}$, and $\mathrm{As}$ in soil ranged from 29 to $931 \mathrm{mg} / \mathrm{kg}, 35$ to $771 \mathrm{mg} / \mathrm{kg}$, and 11 to $198 \mathrm{mg} / \mathrm{kg}$, respectively. The amount of microbial biomass carbon expressed on a soil organic carbon basis decreased with increasing concentrations of heavy metals. Thus, the heavy metals that accumulated in apple orchard surface soils had adverse effects on the soil microbial biomass. The analysis of phospholipid fatty acid (PLFA) composition indicated that the microbial community structure had changed because of the pesticide-derived heavy metals in soil. The relative abundance of gram-positive bacterial marker PLFAs increased and that of fungal marker PLFA decreased with increasing concentrations of heavy metals in soil. Denaturing gradient gel electrophoreses targeting the $16 S$ ribosomal RNA gene of bacteria and the $18 S$ ribosomal RNA gene of fungi also showed shifts in the composition of bacterial and fungal communities induced by soil pollution with heavy metals. However, the diversity of microbial communities was not significantly affected by the heavy metal pollution. This was attributable to the adaptation of the microbial communities in apple orchard surface soils to heavy metals derived from previously used pesticides.
\end{abstract}

Keywords: Apple Orchard; Denaturing Gradient Gel Electrophoresis; Heavy Metals; Microbial Biomass; Metal-Based Pesticides; Soil Pollution; Phospholipid Fatty Acid

\section{Introduction}

Soil pollution with heavy metals occurs not only near mines and smelters, but also on agricultural land because of the application of sewage sludge and metal-based pesticides. In Japan, long-term use of Bordeaux mixtures and lead arsenate has led to the pollution of apple orchard surface soils with copper $(\mathrm{Cu})$, lead $(\mathrm{Pb})$, and arsenic (As) [1]. The highest concentrations of $\mathrm{Cu}, \mathrm{Pb}$, and As found in alluvial apple orchard surface soils $(0-10$ $\mathrm{cm}$ ) were 1120,1810 , and $260 \mathrm{mg} / \mathrm{kg}$, respectively [1]. The use of lead arsenate was prohibited in 1978, while Bordeaux mixtures are still utilized in Japan. However, most apple growers stopped the use of Bordeaux mix-

\footnotetext{
"Corresponding author.
}

tures by the early 1990s to avoid accumulation of $\mathrm{Cu}$ in soil.

Heavy metal pollution exerts toxic effects on soil microbial biomass [2-5] and microbial processes such as soil respiration, nitrogen mineralization, and enzyme activities [6-8]. Therefore, we investigated the effects of heavy metal accumulation on the microbial biomass and microbial activities in apple orchard soils [1,9]. The results indicated that among the heavy metals, the adverse effects were primarily brought about by $\mathrm{Cu}$, which accumulated in apple orchard soils [1,9]. With increasing total concentration of $\mathrm{Cu}$ in apple orchard soils, the proportion of microbial biomass in the soil organic matter decreased, and the contribution of fungi to substrateinduced respiration increased [9]. Furthermore, the de- 
hydrogenase activity and soil respiration expressed on a unit of soil organic carbon basis were negatively correlated with the amount of $0.1 \mathrm{M} \mathrm{CaCl}_{2}$-extractable $\mathrm{Cu}[1,9]$. Thus, microbial biomass and microbial activities were shown to be adversely affected by the $\mathrm{Cu}$ accumulated in apple orchard surface soils. It was also demonstrated by a field-incubation study that the toxicity of $\mathrm{Cu}$ to the microbial biomass and microbial activities was largest among the three heavy metals, $\mathrm{Cu}, \mathrm{Pb}$, and $\mathrm{As}$ [10].

In addition to microbial biomass and microbial activities, the diversity of the microbial communities is an important index of soil quality. Molecular techniques such as phospholipid fatty acid (PLFA) analysis and nucleic acid-based techniques have recently been developed for characterizing soil microbial communities [11,12]. Analysis of the PLFA pattern has been applied to investigate the impact of heavy metal pollution on soil microbial communities [13-19]. In most cases, shifts in the PLFA pattern due to heavy metal pollution were observed. Although there is a good correlation between the total amount of PLFAs and microbial biomass in soil [20], PLFA analysis always has a much stronger focus on bacterial communities than on fungal communities [21]. Therefore, PLFA analysis is more suitable for differentiating between different functional bacterial groups, e.g., actinomycetes, gram-negative bacteria and gram-positive bacteria, than between fungal and bacterial biomass.

Nucleic acid-based techniques have been also used for studying the effects of heavy metal pollution on soil microbial community. Polymerase chain reaction (PCR)-denaturing gradient gel electrophoresis (DGGE) in particular has been used for the assessment of the bacterial community structure in soils with heavy metal pollution [22-27]. Other PCR-amplified DNA fingerprinting techniques, e.g., amplified ribosomal DNA restriction analysis and terminal-restriction fragment length polymerphism, were used for investigating the bacterial communities in heavy metal polluted soils [15,28-32]. The application of PCR-amplified DNA fingerprinting techniques succeeded to discriminate the community structures between heavy metal-polluted and unpolluted soils for both bacteria and fungi.

Our objective in the present study was to determine the effects of heavy metals accumulated in apple orchard surface soils on microbial biomass and microbial communities. We used PLFA analysis for assessing the diversity of soil microbial communities on the phenotype level and differentiating the microbial biomass into functional subgroups, i.e., gram-negative bacteria, gram-positive bacteria, actinomycetes, and fungi, and PCRDGGE was used for assessing the diversities of bacterial and fungal communities separately on a genotype level.

\section{Materials and Methods}

\subsection{Soil Sampling}

Soil samples A-F were taken from one chestnut orchard and five apple orchards in May 2006. Soils A and B were taken from a chestnut orchard and an apple orchard, respectively, at the Fujisaki Experimental Farm of Hirosaki University, and soils $\mathrm{C}-\mathrm{F}$ were taken from commercial apple orchards in Fujisaki Town, Aomori Prefecture, Japan. For each orchard, four trees were chosen randomly and soil samples were taken from the $0-10 \mathrm{~cm}$ layer just beneath the canopy of the trees. All soils were alluvial soils classified as Dystric Fluvisols (FAO/ UNESCO). Each moist soil sample was passed through a 2-mm mesh sieve. The moist soil samples were used for the measurement of microbial biomass carbon and PCRDGGE, and part of the moist soil samples were freezedried for PLFA analysis. The residual samples were airdried for chemical analyses.

\subsection{Chemical Analyses}

The soil $\mathrm{pH}$ was determined with a glass electrode in water using a soil-to-water ratio of 1:2.5. The total carbon and nitrogen contents were simultaneously determined using a Sumigraph NC-90A automatic analyzer (Sumitomo Chemical Co., Ltd., Osaka, Japan). Since carbonates were not present, the total carbon content was equivalent to the organic carbon content. For determining the total amounts of $\mathrm{Cu}, \mathrm{Pb}$, and $\mathrm{As}$, the soil samples were digested with a $\mathrm{HClO}_{4}-\mathrm{HNO}_{3}-\mathrm{H}_{2} \mathrm{SO}_{4}$ mixture, and $\mathrm{NH}_{4} \mathrm{Cl}$ was subsequently added to the digestion mixture to prevent the co-precipitation of $\mathrm{Pb}$ [33]. The total contents of $\mathrm{Cu}$ and $\mathrm{Pb}$ were determined by atomic absorption spectrometry, and the content of As was determined colorimetrically by using silver diethyldithiocarbamate [33].

\subsection{Microbial Biomass Carbon}

Moist soil subsamples equivalent to $60 \mathrm{~g}$ oven-dry soil were weighed in $200-\mathrm{mL}$ plastic beakers, adjusted to $60 \%$ of the maximum water holding capacity with distilled water, and then pre-incubated for $7 \mathrm{~d}$ at $25^{\circ} \mathrm{C}$. Microbial biomass carbon $\left(\mathrm{C}_{\text {mic }}\right)$ was measured using the fumigation-extraction procedure proposed by Vance et al. [34]. Briefly, a portion of the pre-incubated soil sample corresponding to $25 \mathrm{~g}$ oven-dry soil was fumigated with alcohol-free chloroform for $24 \mathrm{~h}$. Organic carbon was extracted from fumigated and unfumigated soil samples with $100 \mathrm{~mL}$ of $0.5 \mathrm{M} \mathrm{K}_{2} \mathrm{SO}_{4}$ and quantified using a TOC analyzer (TOC- $\mathrm{V}_{\mathrm{E}}$; Shimadzu Co., Ltd., Kyoto, Japan). A $k_{\mathrm{EC}}$ factor of 0.45 was used to estimate $\mathrm{C}_{\text {mic }}$ from extractable organic carbon [35]. 


\subsection{PLFA}

Soil lipids were extracted from $4 \mathrm{~g}$ of freeze-dried soil with 10:5:4 volumes of methanol, chloroform, and $0.1 \mathrm{M}$ phosphate buffer ( $\mathrm{pH}$ 7.0) by using a modified Bligh and Dyer [36] technique as described in Balser and Firestone [37]. PLFAs were separated by silica gel chromatography (Supelco LC-Si SPE cartridges) and methylated by using a methanolic $\mathrm{KOH}$ solution. The PLFA-methyl esters were analyzed using both a GC-14B gas chromatograph (Shimadzu Co., Ltd., Kyoto, Japan) equipped with a flame ionization detector and a GCMS-QP2010 gas chromatograph-mass spectrometer (Shimadzu Co., Ltd., Kyoto, Japan). A DB-5 capillary column $(0.32 \mathrm{~mm}$ $\times 30 \mathrm{~m}$; Agilent Technologies Inc., Santa Clara, CA, USA) was used for gas chromatographic separation. Standards containing mixtures of 37 and 24 fatty acid methyl esters (Sigma-Aldrich Japan Co., Tokyo, Japan) were used to help with peak identification. PLFA 19:0 was used as internal standard. The PLFAs were designated in terms of total number of carbon atoms, double bonding and position of the double bonds. The suffixes "c" and " $\mathrm{c}$ " indicate cis and trans geometric isomers. The prefixes " $i$ " and " $a$ " refer to iso and anteiso methyl branching. Hydroxy groups are indicated by "OH". Cyclopropyl groups are denoted by "cy", "10 Me" refers to a methyl group on the tenth carbon from the carboxylic end of the fatty acid. The following PLFAs were identified and quantified: i-14:0, a-14:0, 14:0, i-15:0, a-15:0,

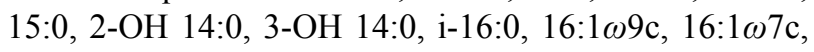

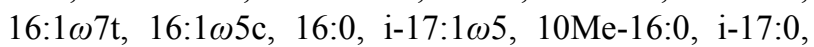
a-17:0, 17:1 $\omega 8 \mathrm{c}, \quad$ cy17:0, 17:0, 2-OH 16:0, i-18:0, $18: 2 \omega 6,18: 1 \omega 9 \mathrm{c}, 18: 1 \omega 7 \mathrm{c}, 18: 1 \omega 7 \mathrm{t}, 18: 1 \omega 5 \mathrm{c}, 18: 0,10$ Me-18:0, i-19:0, cy19:0, 20:4, and 20:0.

\subsection{PCR-DGGE}

DNA was extracted from soil samples $(0.25 \mathrm{~g})$ using a MO BIO UltraClean Soil DNA Isolation Kit (MO BIO Laboratories, Inc., Carlsbad, CA, USA) according to the manufacturer's specifications. The primer pairs $357 \mathrm{~F}-$ $\mathrm{GC} / 517 \mathrm{R}$ [38], targeting the $\mathrm{V} 3$ region in the $16 \mathrm{~S}$ ribosomal RNA (rRNA) gene for bacteria, and FF390/ FR1GC [39], targeting the $18 S$ rRNA gene for fungi, were used for PCR amplification. In the PCR reaction, $5 \mu \mathrm{L}$ of a 50-fold diluted DNA extract was added to the PCR mix, which was composed of $5 \mu \mathrm{L}$ of $10 \times$ PCR buffer, $4 \mu \mathrm{L}$ dNTPs (10 mmol/L each), $0.5 \mu \mathrm{L}$ of each primer $(25$ $\mathrm{mmol} / \mathrm{L}), 0.5 \mu \mathrm{L}$ Taq polymerase $(5 \mathrm{U} / \mu \mathrm{L})$, and ultra pure water to a total volume of $50 \mu \mathrm{L}$. PCR conditions for bacteria were as follows: an initial denaturation at $95^{\circ} \mathrm{C}$ for $10 \mathrm{~min}$, followed by 35 cycles of 30 -sec denaturation at $93^{\circ} \mathrm{C}$ and $30-\mathrm{sec}$ annealing at $65^{\circ} \mathrm{C}$ (first 10 cycles), then at $60^{\circ} \mathrm{C}$ (second 10 cycles), and finally at $55^{\circ} \mathrm{C}$ (last
15 cycles). Each annealing step was followed by a $1-\mathrm{min}$ extension at $72^{\circ} \mathrm{C}$, except for the final extension (at $72^{\circ} \mathrm{C}$ for $5 \mathrm{~min}$ ). PCR conditions for fungi were as follows: denaturation for $8 \mathrm{~min}$ at $95^{\circ} \mathrm{C}$, then 30 cycles of denaturation at $95^{\circ} \mathrm{C}$ for $30 \mathrm{sec}$, annealing at $50^{\circ} \mathrm{C}$ for 45 sec, followed by extension at $72^{\circ} \mathrm{C}$ for $2 \mathrm{~min}$, and a final extension at $72^{\circ} \mathrm{C}$ for $10 \mathrm{~min}$. After amplification, PCR products were verified by electrophoresis on a $2 \%$ agarose gel followed by staining with SYBR Gold (Invitrogen Corp., Carlsbad, CA, USA).

For bacteria, DGGE was performed using the double gradient technique [40]. PCR products were loaded onto a $6 \%-12 \%$ polyacrylamide gradient gel with a denatureing gradient ranging from $30 \%$ to $60 \%$. For fungi, a $6 \%$ polyacrylamide gel with a denaturing gradient ranging from $20 \%$ to $50 \%$ was used. One hundred percent of denaturant corresponded to $7 \mathrm{M}$ urea and $40 \%(\mathrm{v} / \mathrm{v})$ formamide. All DGGE analyses were run using a V20HCDC denaturing gradient gel electrophoresis unit (SciePlas Limited, Southam, Warwickshire, UK) at a constant temperature of $60^{\circ} \mathrm{C}$. Electrophoresis was carried out for $10 \mathrm{~min}$ at $150 \mathrm{~V}$ and continued for $16 \mathrm{~h}$ after lowering the voltage to $70 \mathrm{~V}$. After electrophoresis, the gels were stained with SYBR Gold and photographed with a digital camera on a blue-light transilluminator (Invitrogen Corp., Carlsbad, CA, USA). Detection and intensity measurement of bands were performed using the Image-J software (NIH-Image, Bethesda, MD, USA).

\subsection{Statistics}

The data obtained from the PLFA analysis $(\mu \mathrm{mol} / \mathrm{kg})$ and the DGGE patterns, according to band intensity and position, were analyzed by principal component analysis (PCA) using an Excel add-in for multivariate analysis [41]. Microbial community diversity was calculated using the Shannon index $\left(H^{\prime}\right): H^{\prime}=\sum p_{i} \ln p_{i}$, with $p_{i}$ representing the proportional abundance of a given PLFA [42]. For DGGE, $p_{i}$ represented the percentage of the integrated density of a band, relative to the sum of all bands in a lane.

\section{Results}

\subsection{Properties of Soils}

The soils had $\mathrm{pH}$ ranging from 4.8 to 6.1 , organic carbon content from $1.2 \%$ to $4.5 \%$, total nitrogen content from $0.10 \%$ to $0.40 \%$ and a $\mathrm{C} / \mathrm{N}$ ratio from 10.8 to 13.2 (Table 1). Total concentrations of $\mathrm{Cu}, \mathrm{Pb}$, and $\mathrm{As}$ in soil $\mathrm{A}$, which was taken from the chestnut orchard with no history of heavy metal pollution, were 29,35 , and $11 \mathrm{mg} / \mathrm{kg}$, respectively. In soil $\mathrm{B}$, which was taken from the apple orchard adjacent to the unpolluted chestnut orchard, total 
concentrations of $\mathrm{Cu}, \mathrm{Pb}$, and As were significantly higher than those in soil A. Compared with soil A, soils $\mathrm{C}$ and $\mathrm{D}$ showed high concentrations for total $\mathrm{Cu}$, but did not for total $\mathrm{Pb}$ and As. This fact indicated that Bordeaux mixtures and not lead arsenate had been used in the apple orchards from where soils $\mathrm{C}$ and $\mathrm{D}$ were taken. In soils $\mathrm{E}$ and $\mathrm{F}$, total concentrations of $\mathrm{Cu}, \mathrm{Pb}$ and As were markedly higher than those in the other soils. This would reflect the long-term use of Bordeaux mixtures and lead arsenate at the apple orchards from where soils $\mathrm{E}$ and $\mathrm{F}$ were taken.

\subsection{Microbial Biomass}

The amount of $\mathrm{C}_{\text {mic }}$ expressed on an oven-dry soil basis was largest in soils A and B and lowest in soil C, indicating that this parameter is not related to the heavy metal concentrations (Table 2). In contrast, the amount of $\mathrm{C}_{\text {mic }}$ expressed on a total soil organic carbon $\left(\mathrm{C}_{\text {mic }} /\right.$ Org-C) decreased with increasing heavy metal concentrations (Table 2). $\mathrm{C}_{\mathrm{mic}} / \mathrm{Org}-\mathrm{C}$ showed a significant negative correlation with the logarithmic concentrations of total $\mathrm{Cu}$ in soil (Figure 1).

\subsection{PLFAs}

The total amount of PLFAs showed a highly significant positive correlation with the amount of $\mathrm{C}_{\text {mic }}$ (Figure 2(a)). Furthermore, total PLFAs calculated per gram of soil organic carbon decreased linearly with increasing logarithmic concentrations of total $\mathrm{Cu}$ (Figure 2(b)), as observed for $\mathrm{C}_{\mathrm{mic}} / \mathrm{Org}-\mathrm{C}$. PCA of the PLFA profiles indicated that there were differences in the PLFA profiles among the soils and the soils were grouped according to the heavy metal concentrations (Figure 3(a)). The soils were mainly separated along PC1, which accounted for $72 \%$ of total sample variance. Scores on PC1 had a strong positive correlation with the levels of $\mathrm{Cu}$ in the soils (Figure 3(b)).

The relative abundance (as molar percentage of total PLFAs) of marker PLFAs specific to gram-negative bacteria, gram-positive bacteria, actinomycetes, and fungi were calculated to investigate the effects of heavy metal accumulation on the individual microbial subgroups (Figure 4). Gram-positive bacteria were represented by $\mathrm{i}$ 14:0, a-14:0, i-15:0, a-15:0, i-16:0, i-17:0, a-17:0, and i-18:0 [43], while gram-negative bacteria were represented by $18: 1 \omega 7 \mathrm{c}$, cy17:0, and cy19:0 [44], actinomycetes by $10 \mathrm{Me}-16: 0$ and $10 \mathrm{Me}-18: 0$ [45], and fungi by 18:2 $\omega 6$ [43]. The relative abundance of gram-positive bacterial marker PLFAs increased and that of fungal marker PLFA decreased, as the heavy metal concentrations of soil increased (Figure 4).

The Shannon index was significantly lower in soil E

Table 1. Chemical properties of the soils used.

\begin{tabular}{cccccccc}
\hline Soil & $\mathrm{pH}$ & $\begin{array}{c}\text { Total organic carbon } \\
(\%)\end{array}$ & $\begin{array}{c}\text { Total nitrogen } \\
(\%)\end{array}$ & $\mathrm{C} / \mathrm{N}$ ratio & $\begin{array}{c}\text { Total } \mathrm{Cu} \\
(\mathrm{mg} / \mathrm{kg})\end{array}$ & $\begin{array}{c}\text { Total Pb } \\
(\mathrm{mg} / \mathrm{kg})\end{array}$ & $\begin{array}{c}\text { Total As } \\
(\mathrm{mg} / \mathrm{kg})\end{array}$ \\
\hline $\mathrm{A}$ & $5.75 \pm 0.02$ & $2.01 \pm 0.18$ & $0.162 \pm 0.013$ & $12.4 \pm 0.2$ & $28.6 \pm 1.2$ & $35.3 \pm 3.3$ & $10.6 \pm 0.9$ \\
$\mathrm{~B}$ & $6.01 \pm 0.03$ & $2.54 \pm 0.06$ & $0.221 \pm 0.011$ & $11.6 \pm 0.4$ & $90.9 \pm 6.2$ & $79.5 \pm 1.7$ & $21.7 \pm 0.7$ \\
$\mathrm{C}$ & $6.13 \pm 0.01$ & $1.26 \pm 0.12$ & $0.097 \pm 0.012$ & $13.2 \pm 0.6$ & $123.9 \pm 25.7$ & $16.7 \pm 2.1$ & $5.4 \pm 0.4$ \\
D & $5.52 \pm 0.02$ & $2.90 \pm 0.28$ & $0.256 \pm 0.025$ & $11.3 \pm 0.3$ & $464.4 \pm 109.0$ & $28.8 \pm 0.9$ & $8.1 \pm 0.2$ \\
E & $4.83 \pm 0.01$ & $3.48 \pm 0.27$ & $0.320 \pm 0.024$ & $10.8 \pm 0.1$ & $654.9 \pm 63.4$ & $535.7 \pm 61.2$ & $139.0 \pm 17.5$ \\
F & $4.97 \pm 0.02$ & $4.54 \pm 0.68$ & $0.396 \pm 0.063$ & $11.6 \pm 0.3$ & $931.3 \pm 103.7$ & $771.0 \pm 99.4$ & $197.9 \pm 20.2$ \\
\hline
\end{tabular}

Values represent means $\pm \mathrm{SE}$.

Table 2. Microbial biomass carbon $\left(\mathrm{C}_{\text {mic }}\right)$ expressed on an oven-dry soil basis and on a total soil organic $\mathrm{C}$ basis $\left(\mathrm{C}_{\mathrm{mic}} / \mathrm{Org}-\mathrm{C}\right)$.

\begin{tabular}{ccc}
\hline Soil & $\mathrm{C}_{\text {mic }}(\mathrm{mg} / \mathrm{kg})$ & $\mathrm{C}_{\text {mic }} /$ Org-C $(\mathrm{mg} / \mathrm{g}$ soil organic carbon $)$ \\
\hline A & $297 \pm 21.6 \mathrm{~b}$ & $14.9 \pm 0.28 \mathrm{c}$ \\
B & $313 \pm 44.2 \mathrm{~b}$ & $12.3 \pm 1.50 \mathrm{c}$ \\
C & $132 \pm 18.5 \mathrm{a}$ & $10.7 \pm 1.72 \mathrm{bc}$ \\
D & $191 \pm 17.2 \mathrm{ab}$ & $6.8 \pm 0.90 \mathrm{ab}$ \\
E & $162 \pm 20.8 \mathrm{a}$ & $4.8 \pm 0.79 \mathrm{a}$ \\
F & $231 \pm 32.2 \mathrm{ab}$ & $5.3 \pm 0.83 \mathrm{a}$ \\
\hline
\end{tabular}

Values represent means \pm SE. Values follows by the same letter do not differ significantly according to Tukey's test, $\mathrm{p}=0.05$. 
and higher in soil D than in soil A (Table 3). However, the differences were very small.

\subsection{PCR-DGGE}

A total of 75 different band positions were identified on the DGGE gel for bacteria, and a total of 106 different band positions for fungi. Within one orchard, the band patterns of four replicates were similar but could still be differentiated by the presence of weak bands and changes in band intensities. Some of the bands disappeared in the soils with heavy metal accumulation, while opposite phenomena were also observed. For both bacteria and fungi, the number of bands and the Shannon index in the apple orchard soils (B-F) were not significantly different from those in the unpolluted chestnut orchard soil (A) (Table 3).

For both bacteria and fungi, PCA of the band pattern can separate soils from different orchards (Figure 5). With increasing concentration of total $\mathrm{Cu}$ in soil, the scores of $\mathrm{PC} 1$ for bacteria increased significantly (Figure 6(a)), while those for fungi decreased significantly (Fig-

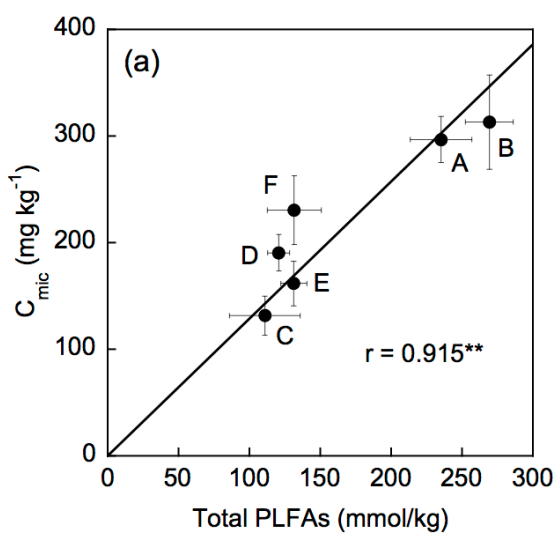

ure 6(b)). Thus, the composition of bacterial and fungal communities changed because of the heavy metals accumulated in apple orchard surface soils.

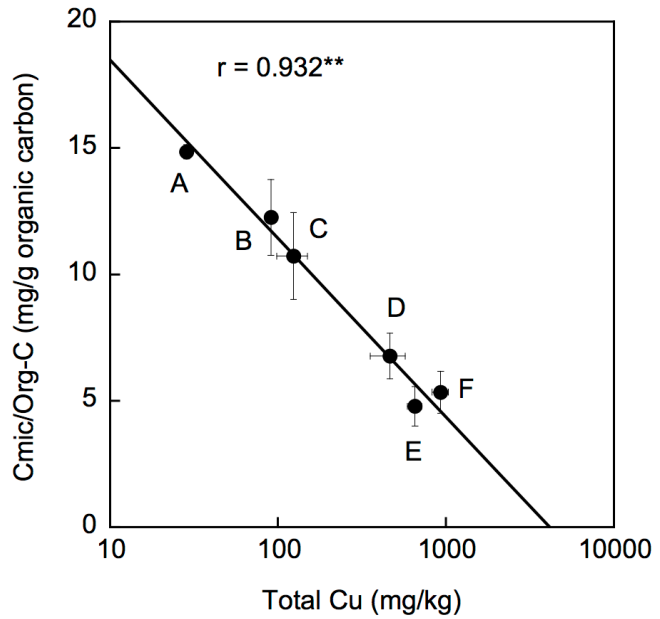

Figure 1. Relationship between the logarithmic concentration of total $\mathrm{Cu}$ and the amount of microbial biomass carbon expressed on a soil organic carbon basis $\left(\mathrm{C}_{\min } / \mathrm{Org}-\mathrm{C}\right)$.

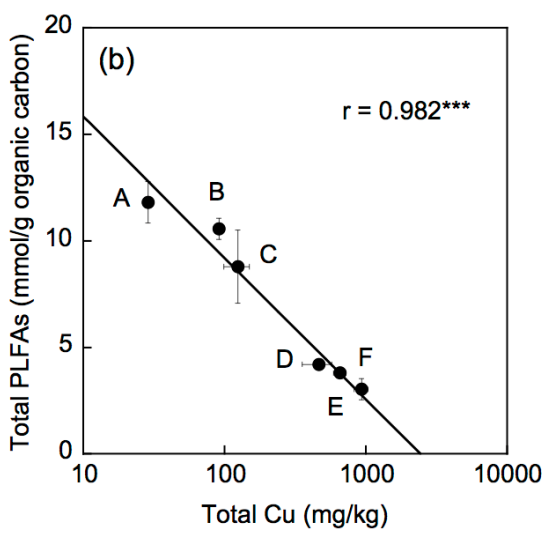

Figure 2. Relationships between the amounts of total PLFAs and microbial biomass carbon (a) and between the logarithmic concentration of total $\mathrm{Cu}$ and the amount of total PLFAs expressed on a soil organic carbon basis (b).
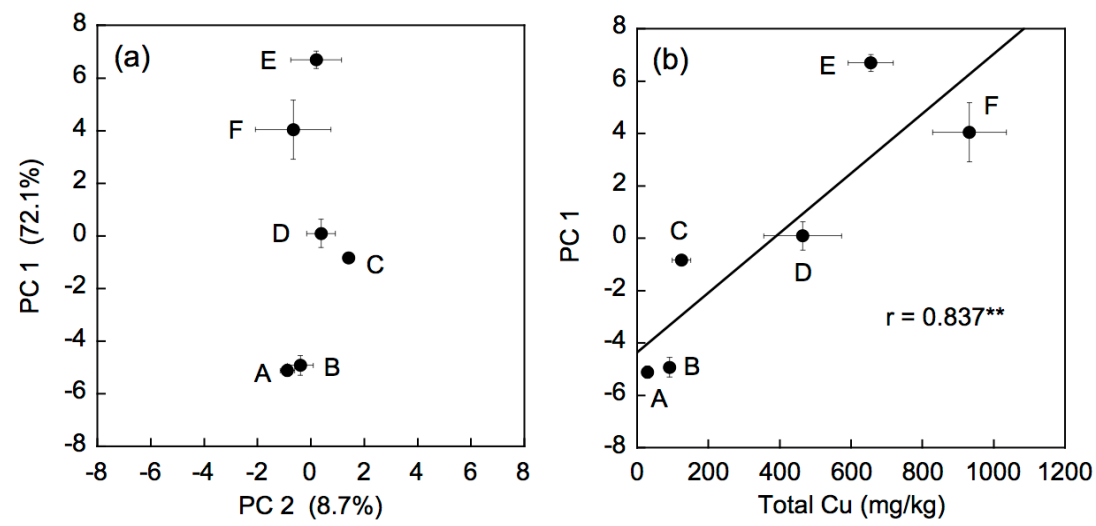

Figure 3. Principal component analysis of PLFA profiles (a) and relationship between total Cu concentrations and scores on PC 1 (b). Values in parentheses denote the variation accounted for by the different components. 


\section{Discussion}

The adverse effects of heavy metals accumulated in apple orchard surface soils on the soil microbial biomass and microbial activities were reported in our previous studies [1,9]. Although 12 years had passed since the soil sampling for the previous studies, significant adverse effects of heavy metals on the soil microbial biomass were still observed. In this period, lead arsenate and Bordeaux mixtures were not used in the apple orchards used in the present study. Thus, the adverse effects on the soil microbial biomass can be attributed to the heavy metals derived from previously used pesticides. Our previous studies have shown that among the heavy metals $\mathrm{Cu}, \mathrm{Pb}$, and $\mathrm{As}$, the toxicity of $\mathrm{Cu}$ to microbial biomass and microbial activities was largest $[1,9,10]$. The present results also suggest that $\mathrm{Cu}$ accumulated in the apple orchard soils significantly affected the soil microbial biomass.

In the present study, we analyzed the amount and composition of PLFAs to investigate which microbial groups were affected by the heavy metals accumulated in the soils. The PLFA patterns of soils with different heavy metal concentrations were differentiated from each other by using multivariate PCA. The scores on PC1 showed a

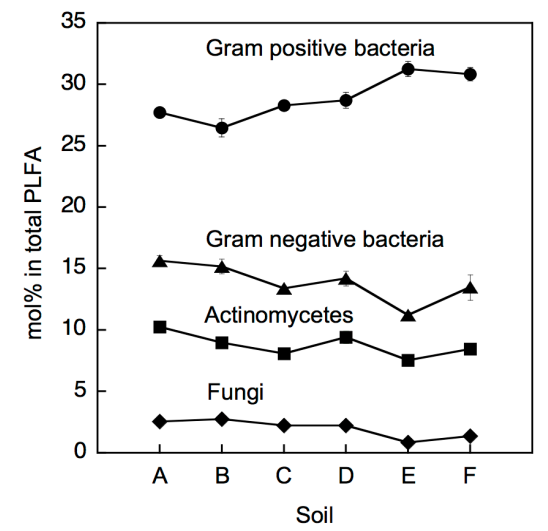

Figure 4. Relative abundance of marker PLFAs specific to gram-negative bacteria, gram-positive bacteria, actinomycetes, and fungi.

Table 3. Shannon indexes for PLFA, bacterial DGGE, and fungal DGGE, and the number of bands observed for DGGE gels.

\begin{tabular}{|c|c|c|c|c|c|}
\hline \multirow{3}{*}{ Soil } & \multirow{3}{*}{$\begin{array}{c}\text { PLFA } \\
\text { (Shannon index) }\end{array}$} & \multicolumn{4}{|c|}{ DGGE } \\
\hline & & \multicolumn{2}{|c|}{ Bacteria } & \multicolumn{2}{|c|}{ Fungi } \\
\hline & & No. of bands & Shannon index & No. of bands & Shannon index \\
\hline A & $2.98 \pm 0.009 b c$ & $30.5 \pm 1.50 \mathrm{a}$ & $3.02 \pm 0.050 \mathrm{a}$ & $36.8 \pm 1.89 \mathrm{ab}$ & $2.92 \pm 0.080 \mathrm{ab}$ \\
\hline B & $3.00 \pm 0.007 \mathrm{~cd}$ & $31.3 \pm 2.84 \mathrm{a}$ & $3.20 \pm 0.071 \mathrm{a}$ & $44.0 \pm 1.29 \mathrm{~b}$ & $3.20 \pm 0.044 b$ \\
\hline $\mathrm{C}$ & $3.02 \pm 0.020 \mathrm{~cd}$ & $21.5 \pm 2.25 \mathrm{a}$ & $2.58 \pm 0.230 \mathrm{a}$ & $31.8 \pm 3.90 \mathrm{a}$ & $3.01 \pm 0.150 \mathrm{ab}$ \\
\hline D & $3.07 \pm 0.011 \mathrm{~d}$ & $23.8 \pm 0.63 \mathrm{a}$ & $2.91 \pm 0.013 \mathrm{a}$ & $33.0 \pm 2.20 \mathrm{ab}$ & $2.82 \pm 0.074 \mathrm{ab}$ \\
\hline E & $2.91 \pm 0.009 \mathrm{a}$ & $26.3 \pm 3.12 \mathrm{a}$ & $2.89 \pm 0.192 \mathrm{a}$ & $32.0 \pm 2.74 \mathrm{a}$ & $2.67 \pm 0.120 \mathrm{a}$ \\
\hline $\mathrm{F}$ & $2.92 \pm 0.026 \mathrm{ab}$ & $28.8 \pm 3.57 \mathrm{a}$ & $3.00 \pm 0.220 \mathrm{a}$ & $30.0 \pm 3.08 \mathrm{a}$ & $2.72 \pm 0.120 \mathrm{a}$ \\
\hline
\end{tabular}

Values represent means \pm SE. Values follows by the same letter do not differ significantly according to Tukey's test, $\mathrm{p}=0.05$.
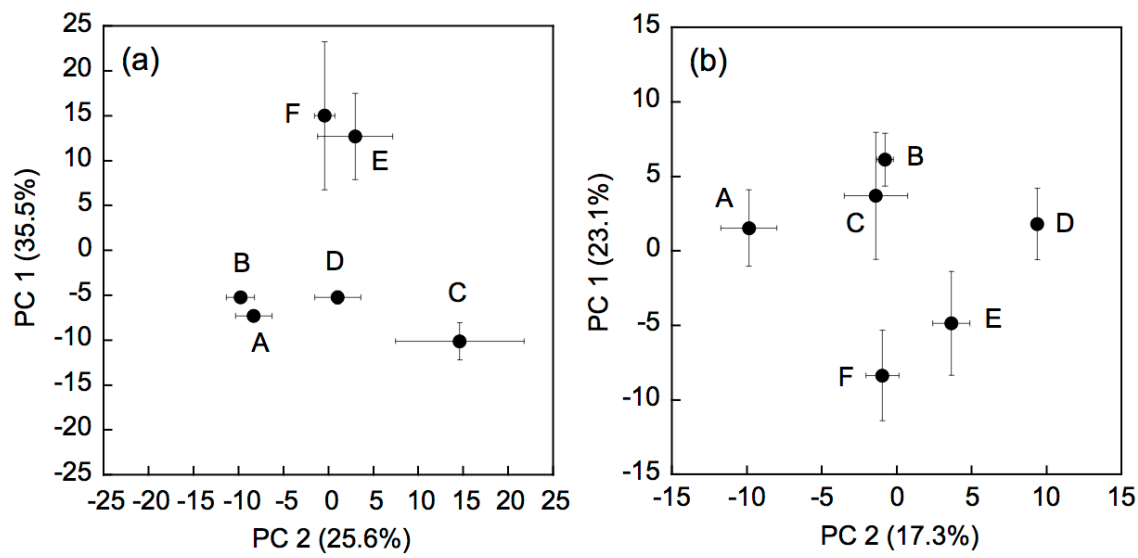

Figure 5. Principal component analyses of DGGE profiles of bacterial community (a) and fungal community (b). Values in parentheses denote the variation accounted for by the different components. 

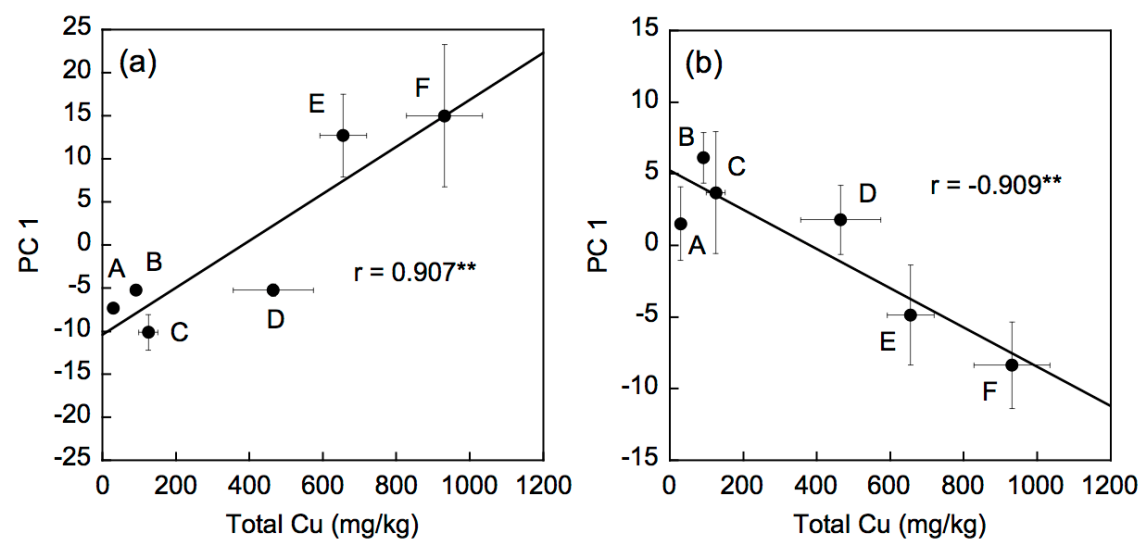

Figure 6. Relationships between tolal Cu concentration and scores on PC 1; (a) bacterial community, (b) fungal community.

highly positive correlation with the concentration of $\mathrm{Cu}$ in the soils. Therefore, the shift in the microbial community composition was ascribed to the pesticides-derived heavy metals accumulated in the apple orchard soils. However, the Shannon index was not appreciably affected by the accumulated heavy metals.

When the percentages of marker PLFAs specific to different microbial groups (relative to the total PLFAs) was used to investigate the effects of heavy metal accumulation on the individual microbial subgroups, the relative abundance of gram-positive bacterial marker PLFAs increased and that of fungal marker PLFA decreased with increasing concentrations of heavy metals in the apple orchard soils. The increase in the relative abundance of gram-positive bacterial marker PLFAs and the decrease in that of fungal marker PLFA have been observed in Scandinavian forest soils polluted with heavy metals, especially with $\mathrm{Cu}$ [19], and in soils amended with sewage sludge containing high concentrations of $\mathrm{Cu}$ [14]. Frey et al. [15] also reported that the relative abundance of fungal marker PLFA decreased by the addition of $\mathrm{Cu}$ and zinc $(\mathrm{Zn})$ to soils.

In our previous study [9], by using selective-inhibition with antibiotics, we estimated the contributions of bacteria and fungi to substrate-induced respiration (SIR) in apple orchard soils. The contribution of fungi to SIR increased with increasing concentration of total $\mathrm{Cu}$ in soil. This fact suggested that the relative abundance of fungal biomass increased as the total $\mathrm{Cu}$ concentration in soil increased, since the SIR is usually correlated with the size of microbial biomass [46]. Fliessbach et al. [4] also reported an increase in the contribution of fungi to SIR in soils receiving sewage sludge contaminated with heavy metals. However, these findings contradict the present result.

Selective inhibition of SIR is based on the assumption that fungi and bacteria respond similarly to a substrate [47]. Rajapaksha et al. [48], who investigated the effects of $\mathrm{Cu}$ and $\mathrm{Zn}$ on the activities of fungi and bacteria, reported that fungal activity was less affected by heavy metals than bacterial activity. Therefore, it is suggested that in soils with heavy metal pollution the fungal contribution to SIR is high compared with the bacterial contribution. Consequently, the abundance of fungal marker PLFA is considered to be more suitable as an index of fungal biomass in heavy metal-polluted soils than the fungal contribution to SIR. Thus, the present results indicate that the heavy metals accumulated in apple orchard soils decrease the relative abundance of fungal biomass.

PCA of the PLFA profiles clearly indicated that the composition of the microbial community was affected by the heavy metals accumulated in apple orchard surface soils. However, PLFA analysis always has a much stronger focus on the bacterial community in soil than on the fungal community, because specificity for fungi is only attributed to $18: 2 \omega 6$ [45]. Therefore, we further applied the PCR-DGGE technique targeting the $16 \mathrm{~S}$ rRNA gene of bacteria and the $18 S$ rRNA gene of fungi for assessing the effects of heavy metals accumulated in apple orchard surface soils on the composition of both the bacterial and fungal communities.

PCA of the band pattern of DGGE clearly indicated that the heavy metals accumulated in apple orchard soils affected the composition of both bacterial and fungal communities. The shift in the composition of the soil bacterial community induced by heavy metals has been reported in several studies that used the PCR-DGGE method [24-26]. Macdonald et al. [28] also showed significant effects of $\mathrm{Cu}$ on soil fungal communities in a field under pasture using a combination of multiplexterminal and terminal restriction fragment length polymorphism profiling approaches. These findings are in accordance with the result of our present study.

For both bacteria and fungi, the richness (number of bands) and diversity (Shannon index) were not signifi- 
cantly lower by the heavy metals accumulated in the soils. Altimira et al. [49] reported for long-term Cu-polluted agricultural soils that the bacterial DGGE profiles were shifted by the pollution but that the values of richness and Shannon index were similar among the soils. They considered that bacterial communities from long-term $\mathrm{Cu}$-polluted soils were well adapted to the high $\mathrm{Cu}$ content. Other studies [50,51] also showed that the bacterial diversity did not change significantly after long-term contamination with $\mathrm{Cu}, \mathrm{Pb}$ and $\mathrm{Zn}$. In contrast, shortterm $\mathrm{Cu}$ pollution in soil induced significant modifications in the bacterial community structure, but these changes were resilient after a few weeks or months [52]. Therefore, the present result indicates that bacterial and fungal communities in apple orchard surface soils were adapted to heavy metals derived from previously used pesticides.

\section{Conclusion}

This study clearly indicated the adverse effects of heavy metals derived from previously used pesticides in apple orchard surface soils on the soil microbial biomass. Analysis of the PLFA composition showed that that of the microbial community was affected by pesticide-derived heavy metals in the soils; the relative abundance of grampositive bacteria increased and that of fungi decreased with increasing concentrations of heavy metals. PCRDGGE targeting the rRNA genes of bacteria and fungi also demonstrated the shifts in the composition of bacterial and fungal communities induced by soil pollution with heavy metals. However, the diversity of the microbial communities was not significantly affected by heavy metal pollution. This could be explained by the adaptation of microbial communities in apple orchard surface soils to heavy metals derived from previously used pesticides

\section{REFERENCES}

[1] M. Aoyama and T. Nagumo, "Factors Affecting Microbial Biomass and Dehydrogenase Activity in Apple Orchard Soils with Heavy Metal Accumulation," Soil Science and Plant Nutrition, Vol. 42, No. 4, 1996, pp. 821831. doi:10.1080/00380768.1996.10416629

[2] K. Chander and P. C. Brookes, "Effects of Heavy Metals from Past Applications of Sewage Sludge on Microbial Biomass and Organic Matter Accumulation in a Sandy Loam and Silty Loam UK Soil," Soil Biology \& Biochemistry, Vol. 23, No. 10, 1991, pp. 927-932. doi:10.1016/0038-0717(91)90172-G

[3] K. Chander and P. C. Brookes, "Residual Effects of Zinc, Copper and Nickel in Sewage Sludge on Microbial Biomass in a Sandy Loam," Soil Biology \& Biochemistry, Vol. 25, No. 9, 1993, pp. 1231-1239.

\section{doi:10.1016/0038-0717(93)90219-2}

[4] A. Fliessbach, R. Martens and H. H. Reber, "Soil Microbial Biomass and Microbial Activity in Soils Treated with Heavy Metal Contaminated Sewage Sludge," Soil Biology \& Biochemistry, Vol. 26, No. 9, 1994, pp. 1201-1205. doi:10.1016/0038-0717(94)90144-9

[5] K. Chander, P. C. Brookes and S. A. Harding, "Microbial Biomass Dynamics Following Addition of Metal-Enriched Sewage Sludges to a Sandy Loam," Soil Biology \& Biochemistry, Vol. 27, No. 11, 1995, pp. 1409-1421. doi:10.1016/0038-0717(95)00074-O

[6] E. Bååth, "Effects of Heavy Metals in Soil on Microbial Processes and Populations: A Review," Water, Air, \& Soil Pollution, Vol. 47, No. 3-4, 1989, pp. 335-375. doi:10.1007/BF00279331

[7] H. Babich and G. Stotzky, "Heavy Metal Toxicity to Microbe-Mediated Ecologic Processes: A Review and Potential Application to Regulatory Policies," Environmental Research, Vol. 36, No. 1, 1985, pp. 111-137. doi:10.1016/0013-9351(85)90011-8

[8] K. E. Giller, E. Witter and S. P. McGrath, "Toxicity of Heavy Metals to Microorganisms and Microbial Processes in Agricultural Soils: A Review," Soil Biology \& Biochemistry, Vol. 30, No. 10-11, 1998, pp. 1389-1414. doi:10.1016/S0038-0717(97)00270-8

[9] M. Aoyama and T. Nagumo, "Effects of Heavy Metal Accumulation in Apple Orchard Soils on Microbial Biomass and Microbial Activities," Soil Science and Plant Nutrition, Vol. 43, No. 3, 1997, pp. 601-612. doi:10.1080/00380768.1997.10414786

[10] M. Aoyama and T. Nagumo, "Comparison of the Effects of $\mathrm{Cu}, \mathrm{Pb}$, and $\mathrm{As}$ on Plant Residue Decomposition, Microbial Biomass, and Soil Respiration," Soil Science and Plant Nutrition, Vol. 43, No. 3, 1997, pp. 613-622. doi:10.1080/00380768.1997.10414787

[11] J. L. Kirk, L. A. Beaudette, M. Hart, P. Moutoglis, J. N. Klironomos, H. Lee and J. T. Trevors, "Methods of Studying Soil Microbial Diversity," Journal of Microbiological Methods, Vol. 58, No. 2, 2004, pp. 169-188. doi:10.1016/j.mimet.2004.04.006

[12] S. Malik, M. Beer, M. Megharaj and R. Naidu, "The Use of Molecular Techniques to Characterize the Microbial Communities in Contaminated Soil and Water," Environment International, Vol. 34, No. 2, 2008, pp. 265-276. doi:10.1016/j.envint.2007.09.001

[13] E. Bååth, A. Frostegård and H. Fritze, "Soil Bacterial Biomass, Activity, Phospholipid Fatty Acid Pattern, and $\mathrm{pH}$ Tolerance in an Area Polluted with Alkaline Dust Deposition," Applied and Environmental Microbiology, Vol. 58, No. 12, 1992, pp. 4026-4031.

[14] E. Bååth, M. Diaz-Ravina, A. Frostegård and C. Campbell, "Effects of Metal-Rich Sludge Amendments on the Soil Microbial Community," Applied and Environmental Microbiology, Vol. 64, No. 1, 1998, pp. 238-245.

[15] B. Frey, M. Stemmer, F. Widmer, J. Luster and C. Sperisen, "Microbial Activity and Community Structure of a Soil after Heavy Metal Contamination in a Model Forest 
Ecosystem," Soil Biology \& Biochemistry, Vol. 38, No. 7, 2006, pp. 1745-1756. doi:10.1016/i.soilbio.2005.11.032

[16] A. Frostegård, E. Bååth and A. Tunlid, "Shifts in the Structure of Soil Microbial Communities in Limed Forests as Revealed by Phospholipid Fatty Acid Analysis," Soil Biology \& Biochemistry, Vol. 25, No. 6, 1993, pp. 723-730. doi:10.1016/0038-0717(93)90113-P

[17] A. Frostegård, A. Tunlid and E. Bååth, "Phospholipid Fatty Acid Composition, Biomass, and Activity of Microbial Communities from Two Soil Types Experimentally Exposed to Different Heavy Metals," Applied and Environmental Microbiology, Vol. 59, No. 11, 1993, pp. 3605-3617.

[18] M. B. Hinojosa, J. A. Carreira, R. García-Ruíz and R. P. Dick, "Microbial Response to Heavy Metal-Polluted Soils," Journal of Environmental Quality, Vol. 34, No. 5, 2005, pp. 1789-1800. doi:10.2134/jeq2004.0470

[19] T. Pennanen, A. Frostegård, H. Fritze and E. Bååth, "Phospholipid Fatty Acid Composition and Heavy Metal Tolerance of Soil Microbial Communities along Two Heavy Metal-Polluted Gradinents in Coniferous Forest," Applied and Environmental Microbiology, Vol. 62, No. 2, 1996, pp. 420-428.

[20] L. Zelles, "Fatty Acid Patterns of Phospholipids and Lipopolysaccharides in the Characterisation of Microbial Communities in Soil: A Review," Biology and Fertility of Soils, Vol. 29, No. 2, 1999, pp. 111-129. doi: $10.1007 / \mathrm{s} 003740050533$

[21] R. G. Joergensen and C. Emmerling, "Methods for Evaluating Human Impact on Soil Microorganisms Based on Their Activity, Biomass, and Diversity in Agricultural Soils," Journal of Plant Nutrition and Soil Science, Vol. 169, No. 3, 2006, pp. 295-309. doi:10.1002/jpln.200521941

[22] I. C. Anderson, P. I. Parkin and C. D. Campbell, "DNAand RNA-Derived Assessments of Fungal Community Composition in Soil Amended with Sewage Sludge Rich in Cadmium, Copper and Zinc," Soil Biology \& Biochemistry, Vol. 40, No. 9, 2008, pp. 2358-2365. doi:10.1016/i.soilbio.2008.05.015

[23] M. E. F. Boivin, G. D. Greve, S. A. E. Kools, A. W. G. van der Wurff, P. Leeflang, E. Smit, A. M. Breure, M. Rutgers and N. M. van Straalen, "Discriminating between Effects of Metals and Natural Variables in Terrestrial Bacterial Communities," Applied Soil Ecology, Vol. 34, No. 2-3, 2006, pp. 103-113. doi:10.1016/i.apsoil.2006.03.009

[24] F. Gremion, A. Chatzinotas, K. Kaufmann, W. von Sigler and H. Harms, "Impacts of Heavy Metal Contamination and Phytoremediation on a Microbial Community during a Twelve-Month Microcosm Experiment," FEMS Microbiology Ecology, Vol. 48, No. 2, 2006, pp. 273-283. doi:10.1016/j.femsec.2004.02.004

[25] Z. Li, J. Xu, C. Tang, J. Wu, A. Muhammad and H. Wang, "Application of 16S rDNA-PCR Amplification and DGGE Fingerprinting for Detection of Shift in Microbial Community Diversity in $\mathrm{Cu}-, \mathrm{Zn}-$, and Cd-Contaminated Paddy Soils," Chemosphere, Vol. 62, No. 8, 2006, pp.
1374-1380. doi:10.1016/j.chemosphere.2005.07.050

[26] Y. P. Wang, J. Y. Shi, H. Wang, Q. Lin, X. C. Chen and Y. X. Chen, "The Influence of Soil Heavy Metals Pollution on Soil Microbial Biomass, Enzyme Activity, and Community Composition Near a Copper Smelter," Ecotoxicology and Environmental Safety, Vol. 67, No. 1, 2007, pp. 75-81. doi:10.1016/j.ecoenv.2006.03.007

[27] X. Zhou, Z. He, Z. Liang, P. J. Stoffella, J. Fan, Y. Yang and C. A. Powell, "Long-Term Use of Copper-Containing Fungicide Affects Microbial Properties of Citrus Grove Soils," Soil Science Society of America Journal, Vol. 75, No. 3, 2011, pp. 898-906. doi:10.2136/sssaj2010.0321

[28] C. A. Macdonald, C. D. Campbell, J. R. Bacon and B. K. Singh, "Multiple Profiling of Soil Microbial Communities Identifies Potential Genetic Markers of Metal-Enriched Sewage Sludge," FEMS Microbiology Ecology, Vol. 65, No. 3, 2008, pp. 555-564. doi:10.1111/j.1574-6941.2008.00538.x

[29] C. A. Macdonald, I. M. Clark, F.-J. Zhao, P. R. Hirsch, B. K. Singh and S. P. McGrath, "Long-Term Impacts of Zinc and Copper Enriched Sewage Sludge Additions on Bacterial, Archaeal and Fungal Communities in Arable and Grassland Soils," Soil Biology \& Biochemistry, Vol. 43, No. 5, 2011, pp. 932-941. doi:10.1016/j.soilbio.2011.01.004

[30] A. Pérez-de-Mora, P. Burgos, E. Madejón, F. Cabrera, P. Jaeckel and M. Schloter, "Microbial Community Structure and Function in a Soil Contaminated by Heavy Metals: Effects of Plant Growth and Different Amendments," Soil Biology \& Biochemistry, Vol. 38, No. 2, 2006, pp. 327-341. doi:10.1016/j.soilbio.2005.05.010

[31] E. Smit, P. Leeflang and K. Wernars, "Detection of Shifts in Microbial Community Structure and Diversity in Soil Caused by Copper Contamination Using Amplified Ribosomal DNA Restriction Analysis," FEMS Microbiology Ecology, Vol. 23, No. 3, 1997, pp. 249-261. doi:10.1111/j.1574-6941.1997.tb00407.x

[32] R. Turpeinen, T. Kairesalo and M. M. Häggblom, "Microbial Community Structure and Activity in Arsenic-, Chromium- and Copper-Contaminated Soils," FEMS Microbiology Ecology, Vol. 47, No. 1, 2004, pp. 39-50. doi:10.1016/S0168-6496(03)00232-0

[33] M. Aoyama and S. Kuroyanagi, "Effects of Heavy Metal Accumulation Associated with Pesticide Application on the Decomposition of Orchard Grass in Soils," Soil Science and Plant Nutrition, Vol. 42, No. 1, 1996, pp. 121131. doi:10.1080/00380768.1996.10414695

[34] E. D. Vance, P. C. Brookes and D. S. Jenkinson, “An Extraction Method for Measuring Soil Microbial Biomass C," Soil Biology \& Biochemistry, Vol. 19, No. 6, 1987, pp. 703-707. doi:10.1016/0038-0717(87)90052-6

[35] J. Wu, R. G. Joergensen, B. Pommerening, R. Chaussod and P. C. Brookes, "Measurement of Soil Microbial Biomass $\mathrm{C}$ by Fumigation Extraction: An Automated Procedure," Soil Biology \& Biochemistry, Vol. 22, No. 8, 1990, pp. 1167-1169. doi:10.1016/0038-0717(90)90046-3

[36] E. G. Bligh and W. J. Dyer, "A Rapid Method of Total Lipid Extraction and Purification," Canadian Journal of 
Biochemical Physiology, Vol. 37, No. 8, 1959, pp. 911917. doi:10.1139/059-099

[37] T. C. Balser and M. K. Firestone, "Linking Microbial Community Composition and Soil Processes in a California Annual Grassland and Mixed-Conifer Forest," Biogeochemistry, Vol. 73, No. 2, 2005, pp. 395-415. doi:10.1007/s10533-004-0372-y

[38] G. Muyzer, E. C. D. Waal and A. G. Uitterlinden, "Profiling of Complex Microbial Populations by Denaturing Gradient Gel Electrophoresis Analysis of Polymerase Chain Reaction-Amplified Genes Coding for 16S rRNA," Applied and Environmental Microbiology, Vol. 59, No. 3, 1993, pp. 695-700.

[39] E. J. Vainio and J. Hantula, "Direct Analysis of WoodInhabiting Fungi Using Denaturing Gradient Gel Electrophoresis of Amplified Ribosomal DNA," Mycological Research, Vol. 104, No. 8, 2000, pp. 927-936. doi:10.1017/S0953756200002471

[40] M. S. Pedro, S. Haruta, M. Hazaka, R. Shimada, C. Yoshida, K. Hiura, M. Ishii and Y. Igarashi, "Denaturing Gradient Gel Electrophoresis Analyses of Microbial Community from Field-Scale Composter," Journal of Bioscience and Bioengineering, Vol. 91, No. 2, 2001, pp. 159165. doi:10.1263/ibb.91.159

[41] H. Yanai, "Excel Statistics: Multivariate Analysis Techniques," OMS, Tokorozawa, Japan, 2005.

[42] J. C. Zak, M. R. Willing, D. L. Moorhead and H. G. Wildman, "Functional Diversity of Microbial Communities: A Quantitative Approach," Soil Biology \& Biochemistry, Vol. 26, No. 9, 1994, pp. 1101-1108. doi:10.1016/0038-0717(94)90131-7

[43] L. Zelles, "Phospholipid Fatty Acid Profiles in Selected Members of Soil Microbial Communities," Chemosphere, Vol. 35, No. 1-2, 1997, pp. 275-294. doi:10.1016/S0045-6535(97)00155-0

[44] J. B. Brant, E. W. Sulzman and D. D. Myrold, "Microbial Community Utilization of Added Carbon Substrates in Response to Long-Term Carbon Input Manipulation," Soil Biology \& Biochemistry, Vol. 38, No. 8, 1997, pp. 2219-2232. doi:10.1016/j.soilbio.2006.01.022

[45] L. Zelles, Q. Y. Bai, R. X. Ma, R. Rackwitz, K. Winter and F. Beese, "Microbial Biomass, Metabolic Activity and Nutritional Status Determined from Fatty Acid Patterns and Poly-Hydroxybutyrate in Agriculturally-Managed Soils," Soil Biology \& Biochemistry, Vol. 26, No. 4, 1994, pp. 317-323. doi:10.1016/0038-0717(94)90175-9

[46] J. P. E. Anderson and K. H. Domsch, "A Physiological Method for the Quantitative Measurement of Microbial Biomass in Soil," Soil Biology \& Biochemistry, Vol. 10, No. 3, 1978, pp. 207-213. doi:10.1016/0038-0717(78)90098-6

[47] J. P. E. Anderson and K. H. Domsch, "Quantification of Bacterial and Fungal Contributions to Soil Respiration," Archiv für Mikrobiologie, Vol. 93, No. 2, 1973, pp. 113127. doi:10.1007/BF00424942

[48] R. M. C. P. Rajapaksha, M. A Tobor-Kapłon and E. Bååth, "Metal Toxicity Affects Fungal and Bacterial Activities in Soil Differently," Applied and Environmental Microbiology, Vol. 70, No. 5, 2004, pp. 2966-2973. doi:10.1128/AEM.70.5.2966-2973.2004

[49] F. Altimira, C. Yáñez, G. Bravo, M. González, L. A. Rojas and M. Seeger, "Characterization of Copper-Resistant Bacteria and Bacterial Communities from Copper-Polluted Agricultural Soils of Central Chile," BMC Microbiology, Vol. 12, 2012, p. 193. doi:10.1186/1471-2180-12-193

[50] R. J. Ellis, P. Morgan, A. J. Weightman and J. C. Fry, "Cultivation-Dependent and -Independent Approaches for Determining Bacterial Diversity in Heavy-Metal-Contaminated Soil," Applied and Environmental Microbiology, Vol. 69, No. 6, 2003, pp. 3223-3230. doi:10.1128/AEM.69.6.3223-3230.2003

[51] H. Deng, X. F. Li, W. D. Cheng and Y. G. Zhu, "Resistance and Resilience of Cu-Polluted Soil after $\mathrm{Cu}$ Perturbation, Tested by a Wide Range of Soil Microbial Parameters," FEMS Microbiology Ecology, Vol. 70, No. 2, 2009, pp. 137-148. doi:10.1111/j.1574-6941.2009.00741.x

[52] L. Ranjard, A. Echairi, V. Nowak, D. Lejon, R. Nouaim and R. Chaussod, "Field and Microcosm Experiments to Evaluate the Effects of Agricultural $\mathrm{Cu}$ Treatment on the Density and Genetic Structure of Microbial Communities in Two Different Soils," FEMS Microbiology Ecology, Vol. 58, No. 2, 2006, pp. 303-315. doi:10.1111/j.1574-6941.2006.00157.x 